\title{
Article \\ Unapologetically Indigenous: Understanding the Doctoral Process through Self-Reflexivity
}

\author{
Chris A. Nelson (iD
}

check for updates

Citation: Nelson, Chris A. 2021.

Unapologetically Indigenous:

Understanding the Doctoral Process through Self-Reflexivity. Genealogy 5:

7. https://doi.org/10.3390/genealogy 5010007

Received: 29 September 2020

Accepted: 12 January 2021

Published: 15 January 2021

Publisher's Note: MDPI stays neutral with regard to jurisdictional clai$\mathrm{ms}$ in published maps and institutional affiliations.

Copyright: () 2021 by the author. Licensee MDPI, Basel, Switzerland. This article is an open access article distributed under the terms and conditions of the Creative Commons Attribution (CC BY) license (https:// creativecommons.org/licenses/by/ $4.0 /)$.
Morgridge College of Education-Higher Education Department, University of Denver, Denver, CO 80208, USA; Christine.Nelson@du.edu

\begin{abstract}
As a K'awaika \& Diné, I revisit my writings to answer a life-informing question, as opposed to just a research question, of how relationships inform and disrupt my meaning-making of being unapologetically Indigenous in the academy. To answer this question, I offer a series of personal stories and relatives to reconnect to what it means to navigate the doctoral process. Through relationality as a methodology, I connect two sets of stories to disrupt the linear and forwardmoving underpinnings of the doctoral process. I connect stories to highlight three dimensions, i.e., authenticity, vulnerability, and intentionality, to develop what it means to be unapologetically Indigenous in the academy.
\end{abstract}

Keywords: indigenous higher education; doctoral process; self-reflexivity

I come from a strong lineage of K'awaika and Diné people. I carry with me and honor the generations who have come before me. Through their energy and resilience, I am able to be the first in my family to receive a bachelor's degree and, subsequently, a doctoral degree. I entered a graduate school to increase the visibility of native people in my field, which is the study of higher education. Specifically, I wanted to engage in research that critically assessed how systems of higher education limited access to college for native students and their communities. When I was in the data collection/analysis and writing phases of the dissertation process, I experienced several life-changing events that significantly delayed my graduation. I now know I did not take the time and care needed to process each of those events, because each time an event happened, I internalized and equated those experiences as me not trying hard enough. The neoliberal tendencies of production and progress guided my understanding of how I needed to keep going at all costs.

I found myself feeling defeated by the doctoral process. I felt like the goal of the defense would forever be elusive. Then, one evening, I experienced a sport-related injury that helped me realize that "completing the dissertation at all cost" was not who I was raised to be. As I sat in the emergency room and I recalled the accident, I remember touching my head and seeing the blood on my hand and immediately saying, "shit, this can't happen. I have a dissertation to write". I did not care that I could have a severe head injury. I was worried about the dissertation.

As my head healed, I could not do any physical activities or be in front of the computer very long. Instead, I began revisiting my handwritten notes in my research notebook, and I would often write about people in my life. The words in my research notes helped me see the humanity and humility in (my) doctoral process. I realized my focus, became being fixated on the deadlines to finish the dissertation. I forgot about the lessons I learned throughout my life. I realized that throughout the doctoral process, particularly the dissertation phase, I became selfish in the learning process and needed to reorient my life and priorities if I was going to finish in a manner that was aligned with my cultural teaching. I would not say that coming to that conclusion was easy and fast. It took many years after completing (my) dissertation that I can see how (my) doctoral process was a journey of trying to figure out the meaning of being unapologetically Indigenous in the academy. 
In this article, I revisit my writings to answer a life-informing question, instead of a research question, of how relationships inform and disrupt my meaning-making of being unapologetically Indigenous in the academy. To answer this question, I offer a series of personal stories and relatives to reconnect to what it means to navigate the doctoral process. The stories and relatives mentioned are analyzed through a power and place framework (Deloria and Wildcat 2001). Through the power and place framework, I connect stories, relatives, and meaningful artifacts across time and space.

Before describing the contents of this article, I preface three points. First, I frame this study by narrowing in on the doctoral process. I view the doctoral process as an intergenerational process, where my process is tethered to experiences that extend beyond the five years when I was a doctoral student. Throughout this article, I introduce stories that came before, during, and after the doctoral process. For me, they are all connected to (my) doctoral process. Second, I intentionally place parentheses around any possessive pronouns describing (my) doctoral process to disrupt the notion that navigating and completing a doctoral degree was solely my own decision. Third, I lean upon Indigenous values of relations to understand how I navigated (my) doctoral process. My goal to is to engage Indigenous scholars and allies of Indigenous scholars, in a conversation of what it means to develop an unapologetically Indigenous doctoral process in the academy stance.

\section{Being Unapologetic}

The call to be unapologetic in spaces where norms and practices are shaped by white supremacy, colonialism, and oppression is growing in popularity through black feminist scholarship (Patterson et al. 2016), migrant/undocumented scholarship (Anguiano 2011; Negrón-Gonzales 2014) and Indigenous parenting practices (Landry 2018). Being unapologetically Indigenous follows similar practices but centers Indigenous knowledge and practices. "Being unapologetically Indigenous in the academy" is a fairly recent phrase, but the concepts informing being unapologetic are not new. Being unapologetically Indigenous in the academy means to resist the academy's oppressive, imperialist, and settler coloniality practices and perspectives and to embrace one's Indigeneity; however, that may be defined, birthed or fostered (Shotton et al. 2018; Smith 2013). "Being unapologetically Indigenous" is not meant to be monolith or dogmatic. What it can be for scholars is a framework to engage in practices of intentionality and accountability while navigating the academy. I do not claim to have the answer to how one navigates (or resists) this dynamic. Therefore, I offer this article as an attempt to outline how I navigated the doctoral process and, through that process, gained a better understanding of what it means to be unapologetically Indigenous in the academy. I have a lot to learn about this concept, so to begin this conversation, I respectfully accept the responsibility of stewarding the stories and lessons taught by my relatives in the best possible manner.

\section{Mapping the Article}

I begin this article by reviewing the existing research around the doctoral and dissertation process. I then share who I am and how "power and place" connects to the analysis and presentation of the shared stories. Next, I share the methodology of stewarding the stories of this article. Then, the stories that articulate how I make sense (and continue to make sense) of developing my voice of being unapologetically Indigenous are illustrated. Through the stories, I share how relationships and relationality transpire through my experiences.

\section{Doctoral Education and Dissertation Process: Literature Review}

When reviewing the higher education literature, two main themes emerge as relevant to this conversation. The first theme explores explicitly how the experiences of doctoral students are described. The second theme of the literature demonstrates how Indigenous value systems, namely the value of relationality, and intersect with the dissertation process. 
Both themes provide insight into the doctoral process and provide space for me to add my narrative with respect to being unapologetically Indigenous in the academy.

In terms of understanding doctoral experiences for students of color, scholars discuss how a doctoral process more often does not align with the individual student (Fox 2009, 2013; González 2006; Shotton 2018). Graduate students of color describe the doctoral process as disenfranchised through limiting one's agency and contributing to tokenism and cultural isolation (Ballew 1996; Fox 2009, 2013; González 2006). Paradoxically, the other space of this research demonstrates how students created and fostered sub-spaces with their experiences that affirmed their existence in graduate schools. Such experiences include diverse faculty and study bodies, family supports, and witnessing the possibilities of their career trajectories (Fox 2009; González 2006; Shotton 2018). This body of knowledge provides a space to further understand the doctoral and dissertation process and gives reasons to investigate how notions of relationality can be used to understand the doctoral process.

When reviewing the research from an Indigenous values-based approach, a more nuanced understanding of doctoral and dissertation experiences can be understood for Indigenous students. Minthorn and Shotton (2018) work aligns with this approach, because she demonstrates how specific Indigenously defined values such as reciprocity inform doctoral experiences. Shotton finds that Indigenous women in doctoral programs center reciprocity as a guiding principle to navigate and make meaning of both positive and negative experiences one endures during the doctoral process. Reciprocity is rooted in honoring relationships and obligations to those relationships. Beyond specific studies that explore Indigenous doctoral student experiences, I find it noteworthy to acknowledge the seminal works of Archibald (2008), Kovach (2010), and Wilson (2008). Their significant scholarly contributions on Indigenous relationality were shepherded through their doctoral dissertations or theses. Relationality grounded their doctoral processes and scholarships, which subsequently continues to live through other scholars influenced by their work.

\section{Who I Am: Positionality \& Framing the Study}

Yá'át'ééh, shik'éí dóó shidine'é. Shi eiyá Christine Nelson yinishyé. Tółání dine'é éí nishłi'. Naaneesht'ézhi dine'é bá shíshchín. Bitahnii dashicheii. Honágháahnii dashinalí. Totádi éí shigan.

I introduce myself as taught by elders and relatives. I share where my family comes from and how I may or may not be related to others. I share my clans to be in relation with others. I cannot recall a time in my life when I was explicitly told that I have a cultural duty to uphold my relations. However, honoring relations was shown in my daily upbringing. As a child, I remember seeing how my paternal great-grandfather would sit outside his home each morning for hours based on my youthful eyes. I always wondered what he was doing, and it wasn't until I was much older that I made the connection that he was looking to the East. Culturally, that is where my people begin the day and offer prayers. I imagine, in addition to greeting the Sun, he was also greeting his four-legged relatives and flourishing crops, which were just down the hill from his house to the East. He never directly told me why he sat facing the East, but he showed me how to be present in life through his physical actions. He showed me that our connection to place meant we have cultural obligations to remember that energy is embodied in all objects, animate and inanimate. He taught me that energy carries a power rooted in honoring our relations. He passed away when I was twelve, and it was not until I was in my thirties when I read the book written by Deloria and Wildcat (2001) did I realize I could situate my greatgrandfather's teachings in an academic space. My great-grandfather, Deloria, and Wildcat provided a relational space I sought while being in the academy. Deloria and Wildcat (2001) discuss the metaphysical orientations of Indigenous ways of knowing. They acknowledge that power is energy that is embodied in everything, whether we think of it as animate or inanimate. Their definition of power is not about asserting oppressive states over one another. Instead, the power (energy) is what connects us, thus strengthening relations. 
The power embodied by my great-grandfather, Deloria, and Wildcat intersected and profoundly affected how I saw Indigenous theory as not just words in a journal article but also the actions that I witnessed by my great-grandfather. In Figure 1, I position these two experiences on a circular path. The circular path represents (my) doctoral process.

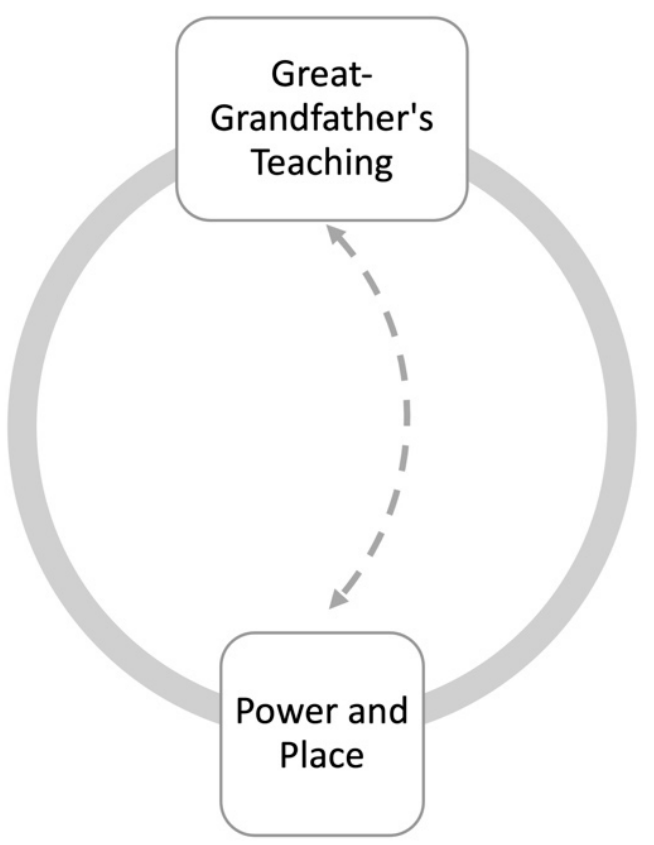

Figure 1. Connecting meaning on (my) doctoral process.

I connect the two experiences with a bidirectional, curved, dashed line to represent my learning process, which is never completed (dashed line) by informing each other (bidirectional) and never overtly direct (curved). The representation of this dynamic is related to the methodology of this work.

\section{Relational Process: Methodology}

In this research, I employ relationality as a methodology. Relationality guides the paradigms informing this work and values relationships to guide how knowledge is created, valued, and lived out. It is important to note that relations can and should extend beyond human interactions and "with all of creation. It is with the cosmos, it is with the animals, with the plants, with the earth that we share this knowledge" (Wilson 2001, p. 177). Through self-reflexivity, I learned how I related to the doctoral process by disentangling and reframing my experiences to create new understandings.

The notion of self-reflexivity is a common approach among various qualitative methodologies (Adams and Jones 2011; Foley 2002; Leary et al. 2009; Parkes 2016; Tomaselli et al. 2008; Ziabakhsh 2015). Self-reflexivity helps researchers locate oneself in relation to power, agency, performativity, and values (Norton and Sliep 2018). For Indigenous research, self-reflexivity also requires layering on the politics of Indigeneity and how Indigeneity transpires in spaces of academia (Kovach 2010). Self-reflexivity offers a powerful tool to encourage researchers to "unsettle previously fixed viewpoints" to foster new perspectives (Hibbert 2013, p. 814).

Self-reflexivity is also found in Indigenous and decolonial research (Kovach 2010; Nicholls 2009; Nilson 2017; Wilson and Wilks 2013). Nicholls (2009) articulates reflexivity as a layering process and identifies three layers one must interrogate. Reflexivity includes self-, inter-, and collective-reflexivity. I apply Nicholls (2009) approach to understand how I engaged with the experience being shared (self), how I related to others in that are involved in that experience (intra), and how community values and norms informed that experience (collective). 
While I find self-reflexivity a helpful approach, self-reflexivity can also be rooted in valuing whiteness and colonial constructs throughout the research process (RussellMundine 2012). The word "self" implies the centering of oneself that can inherently reify individualistic notions of colonialism. I continue with the use of self-reflexivity by honoring the words of Martin and Mirraboopa (2003). They state, "Reflexivity is a process that allows us to work from Aboriginal centres and ensure we work with relatedness of self and Entities. Reflexivity challenges us to claim our shortcomings, misunderstandings, oversights and mistakes, to re-claim our lives and make strong changes to our current realities" (p. 212). I still feel the tensions of self-reflexivity, and to ground myself, I remind myself this process works toward a decolonial space that is never fully found but can exist by imagining the possibilities (La Paperson 2017). To orient self-reflexivity as imagining a decolonial future, I engage in numerous self-talking sessions and talking sessions with close colleagues. The act of vocalizing my experiences and asking someone outside of myself to hear these experiences allows me to un-learn and re-learn.

\section{Origins of Stories (Data)}

When I began writing reflections in my research journal, I started writing personal reflections because I needed a space to reflect and remind myself where I was. Twenty-five entries inspired the upcoming stories about the doctoral process between 2013 and 2016 and five audio recordings from 2014 to 2015. While this documentation process was not initially intended for academic scholarship, I see the value in these reflective pieces because they were used as a catalyst to recalling critical points in time. These points in time required me to search for threads of relations and relatives who influenced (my) doctoral process. The stories I share serve as data to help me articulate (my) doctoral process. Indigenous scholars (Archibald 2008; Kovach 2010; Tachine 2015) state that stories and self-reflection are powerful methods of inquiry. A story is a living entity in that a story told at a younger age may have a different meaning when you are older (Archibald 2008). Indigenous storytelling harnesses this phenomenon to teach life lessons and to validate one's role in society. For this inquiry, storytelling deconstructs the linearity of (my) doctoral process and reconstructs (my) doctoral process as operating on a circular continuum.

\section{Connecting the Stories}

In this section, I share two sets of stories highlighting how each set of stories work together to demonstrate the dynamic nature of relationality that helps me make meaning of (my) doctoral process. Figure 2 is a linear timeline of the stories highlighted in this piece. I provide a linear timeline to give context in the order how the stories occurred in my life.

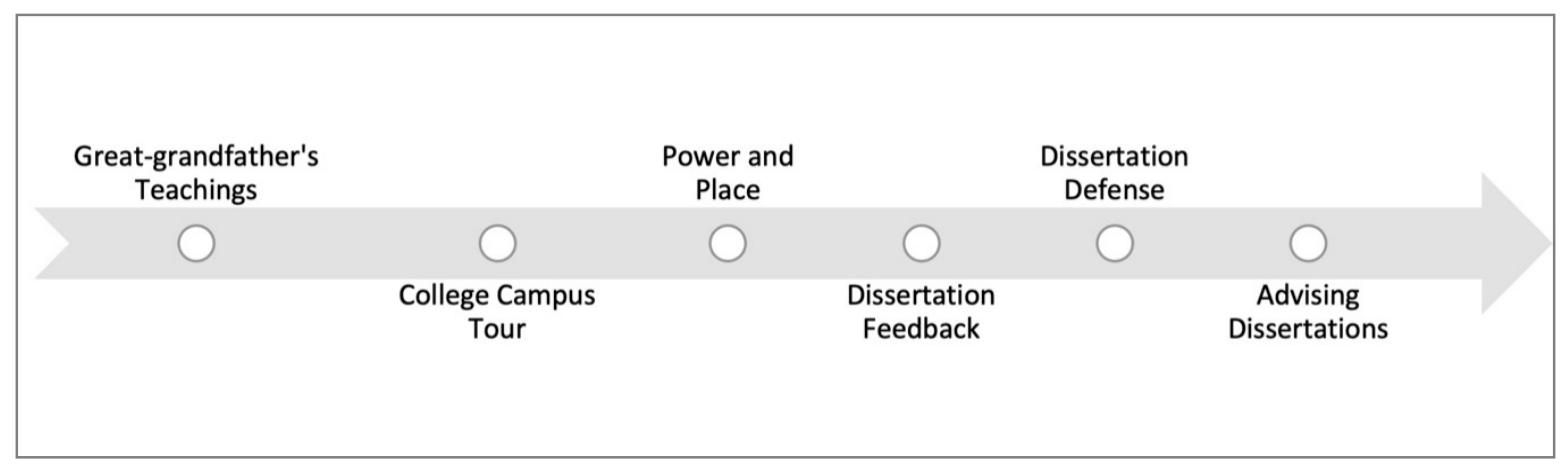

Figure 2. Linear timeline of stories.

The linear timeline represents the notion that progress means to move forward. While linearity may imply knowledge is scaffolded over time, the forward motion does not encourage cyclical learning and reflection. This line also helps shape how I define (my) doctoral process. According to this timeline, one could argue that (my) doctoral process is 
only from "Power and Place" to "Dissertation Defense". However, for me, (my) doctoral process began and extended beyond the graduate school.

Figure 3 demonstrates how I disrupted the linearity of (my) doctoral process. The larger circle represents (my) doctoral process. On the circle lies the stories shared in this article. The dashed lines connecting the stories demonstrate how I situate and layer my interpretation of stories influencing (my) doctoral process. The line is intentionally dashed, because each set of story is coupled for the purpose of this article and should not be interpreted as being solely or permanently coupled.

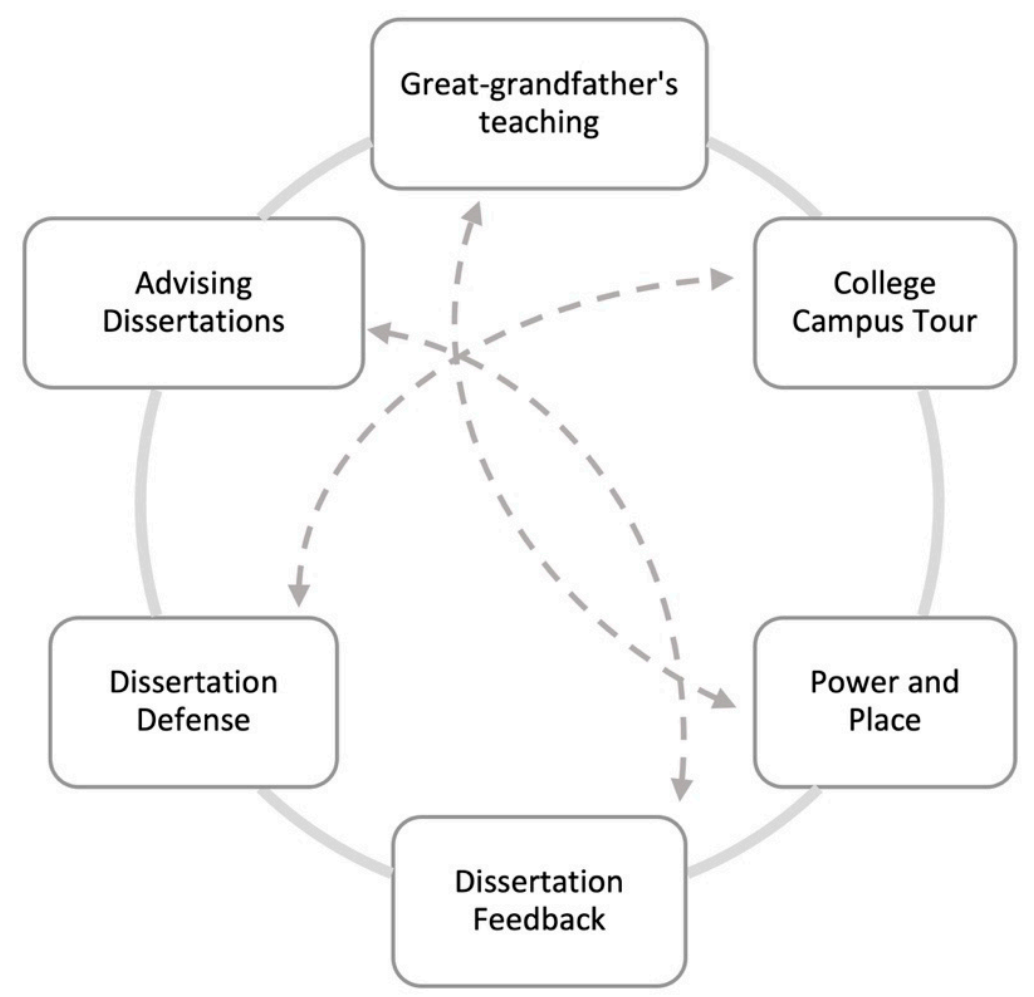

Figure 3. Cyclical continuum of stories.

Furthermore, the dashed lines intersect at one meeting point. I position the lines to show I am intentionally connecting these stories. The arcs of the lines may change over time, and the points of intersections will change. Changing intersections means I will continually learn from the same stories and reinterpret the stories as new stories enter my life. At this moment, these sets of stories have worked together to help me identify how authenticity and vulnerability helped me define what is unapologetically Indigenous in the academy means. For each set, I first share each pair of stories. Then, I frame a discussion using Norton and Sliep (2018) dimensions of dialogical space (power, performance, agency, and values) to present my articulation of being authentic and vulnerable.

\section{Set \#1: Dissertation Defense Meets College Campus Tour}

The stories shared in set \#1 retell (my) dissertation defense and my first experience on a large college campus at the age of 18 .

\subsection{Dissertation Defense: You Did It!}

My hands felt cool. My heart was racing. Voices of the crowd in the hallway sounded muffled, but as I entered the hallway, I heard my dissertation advisor clearly say, "I would like to present to you, Dr. [redacted]". I was ushered along a line of about 15 people. I received hugs and congratulations from various folks, including my mom, son, partner, colleagues, university staff, and students. It was all very overwhelming. 
The 15 or so minutes were a blur, and as things started to calm down, I sat down on a cushy, blue chair that was part of a long line of other blue chairs. I took a deep breath and was handed a greeting card. I opened the card and saw so many names and notes of congratulations. It was emotional to read the short messages, but one message stood out the most. The message read: "I still remember the story you told us during [the pre-college summer program] about how you visited [that university at the age of 18] and got so overwhelmed that you never came back. The fact that you went from that to this is so inspiring! You are a role model for me and so many others! You did it! Congratulations!"

I closed the card, gave a little smirk about that student's comment and thought about my journey to defending my dissertation process. I looked up to not let the tears build up, and just as I took another deep breath, I saw my son asking if we could leave.

\subsection{College Campus Tour: Never Went Back}

My pre-college experience could best be described as a paradox of realities. One reality is that I was moderately primed to be college-ready when I graduated from a high school. I attended several pre-college access programs at multiple universities. I had plenty of scholarships to cover tuition and housing. I felt academically prepared with my ACT score of 24. The other reality was that despite being academically advanced my senior of high school, where I only needed to take two courses to graduate, my high school counselor suggested I enroll in the vocational program at a local community college. Rather than enrolling in Physics or Calculus, I was pushed to learn vocational skills that would help me join the workforce. I attribute my first-generation college student status as not knowing what the possibilities were. I did have an older brother who attended a state college, but he returned home after two years. I saw college as a viable option, but how to navigate that reality was something I was not prepared for.

At the age of 18, two months before the high school graduation, I decided to attend an out-of-state college. I had paid my registration and housing deposits. And per the new student packet, the next step was a campus tour. I had never been to this college campus before, but I was familiar with the large metropolitan city it was located in. So, armed with my optimism and my best friend, we began the seven-hour drive to complete the campus tour.

After confidently navigating the city freeways, I was on my future college campus to only see the car clock reading 8:55 a.m. Sweat was rolling down my face. The double-door entrance to the 9:00 a.m. campus tour was twenty feet away from me, but I continued to drive my 1985 Ford LTD for 15 or so more minutes. After circling the building several times, I realized I had to park a few blocks away at a paid parking garage. Sweating more, and probably looking quite disheveled, I entered the glass doors only to be told, "Sorry, the campus tour already left. You can come back at 1:00 p.m.".

I never went back.

\subsection{Being Authentic}

Authenticity means that one takes time to understand who they are and how they wish to engage in different situations. Seeing how my pre-college experiences informed how a student saw me defending (my) dissertation helped me further reflect upon why I choose to share my college campus tour experience through an authentic approach.

When I decided to not return to campus, I was ashamed of my decision. I was ashamed that I lost my enrollment fee and housing fee because I was scared to return. After becoming a scholar in higher education and becoming familiar with the psychological and environmental factors influencing reasons why individuals go to college, I realized that my 18-year-old decision could have been influenced by systemic inequities that I was not fully aware of. My 18-year-old self did not know how to name systemic inequities in education and how those systems privileged certain groups while disenfranchising others. I internalized my choice to not return as an individual failure. Afterall, I was a 
first-generation college student who did not have any college coaching from my school counselors. Being an academically high-achieving Native student attending a high school located in a town that borders one of my tribes, I am convinced that I experienced unfavorable educational tracking. As I never heard of my non-Native peers, who took the same advanced classes during our junior year and were encouraged by school counselors to enroll in vo-tech programs or to not take advanced science or math courses during their senior year, I cannot say that if I received proper college coaching in high school, I would have enrolled myself in my first college pick. But what I can say is that I was unaware that I was operating in an educational system that was not supporting me. So, for years following my decision to not return after missing the college campus tour, I was ashamed of my choice and chalked up my decision as being afraid. However, situating my experience with academic knowledge and my former student's message, I am now able to reframe my decision. My decision not to return was an act of agency. I chose not to be in a space that was not conducive to what I felt comfortable with.

Reframing my decision helped me further question and analyze what drove my agency not to enroll. Today, I begin to understand how my cultural value of family and community informed my decision-making. Honoring my relations gave me the space to realize there were external factors influencing my college choice decision. One significant factor that occurred when I was deciding which college to attend was the loss of friends. The summer before college, I lost three friends, all in violent matters. Growing up in a border town to the Navajo Nation, violence against the death of young natives permeated my social life (Bennett 2018; Yazzie 2014). I knew it was not normal, but in reflecting upon this time, I realized that I never told an adult in my life about what I was going through and the loss I experienced. I remember one death that happened when I was attending a summer camp away from home. I was on the phone with my friend, and I felt helpless that I could not be there. I began to worry about what it would mean for me to be far away from my hometown and community and what would it mean if I something like this happened again when I was not home. When I returned home from the summer camp, my circle of friends felt different. I never got to properly say goodbye to my friend. I was frustrated and worried that this disconnection would continue if I went to college. During the rest of that summer, I clung to my family and friends. I did not want to be disconnected like I was when I was at the summer camp. The need to have relationships and feel connected was more important to me during that time, and when I was on that big college campus, feeling lost, I recoiled from that space.

Figure 4 visually shows how power, agency, and values transpired within set \#1 stories. My willingness to be authentic in my story shared with one student helped me (and them) make new meaning of experiences. Authenticity comes from a place of being humble in our experiences and pushing ourselves to question our understanding of situations. In the case of sharing my college campus tour experience, my former student's words remind me how stories have agency. They embody energies (Deloria and Wildcat 2001) that can reshape experiences and learning. The connection my student made to my experiences also helped me understand how important it is for me to continue my work in higher education through a relational lens. My Indigenous presence in the academy fosters the opportunity to bring my authentic voice and encourage other Native students to do the same.

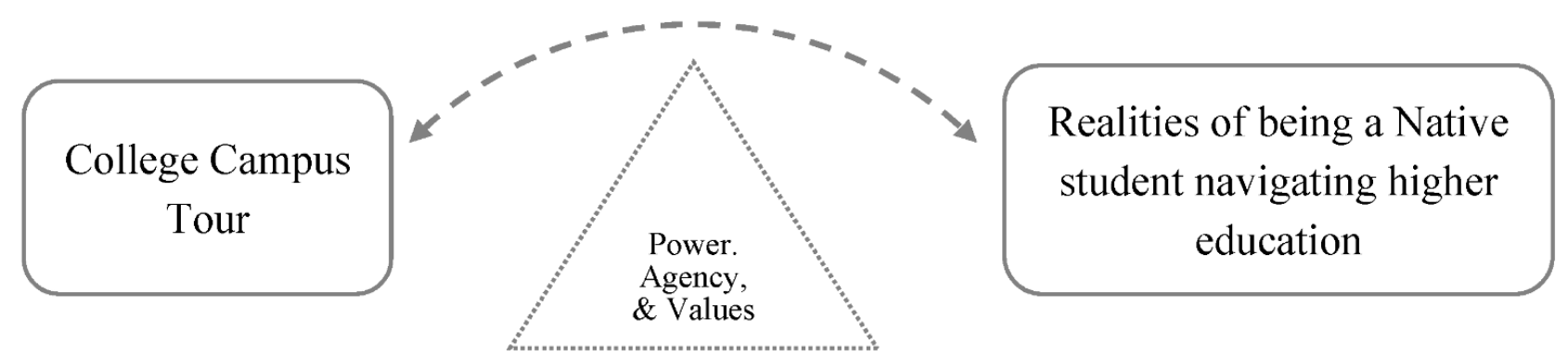

Figure 4. Power, agency, and values. 


\section{Set \#2: Dissertation Advice Meets Dissertation Feedback}

The stories shared in set \#2 are the first time I served on a dissertation committee since becoming a faculty member and when I received the dissertation feedback that told me I did not use Indigenous methodologies.

\subsection{Dissertation Advice: You Enter as You Are}

I entered the classroom where one of a few Indigenous students in my college was getting ready to defend their (using non-binary pronouns) dissertations. I hugged them and asked how things were going. Their replies were confident, and their confidence helped me navigate my nerves. After all, this dissertation defense was the first faculty experience of the dissertation committee facing an Indigenous student. I questioned if I was "qualified" or "ready"to assess another Indigenous person's research. I was also not sure of my role in this defense, because I was the third reader of the dissertation, and the student was not in my department. The student asked me to be on their committee because they were doing research that involved Indigenous methodologies, and I was the only Indigenous scholar in the college that had that specific content knowledge.

The defense presentation went smoothly, and when it came to the committee questions, there was one question about methodology. A committee member alluded to the student's unclear methodologies. The committee member questioned whether the student was properly applying Indigenous methodologies. The student respectfully stated the tension she felt when trying to describe methodologies. I sat and listened to the student's response, but I felt the need to push back on the committee member's question.

I turned to the student and said, "You are an Indigenous person. Throughout your study, you clearly enter the space with your Indigeneity. Your orientation is rooted in Indigenous ways. You are doing Indigenous methodologies. It just so happens that the colonial constructs of research are easier to access and fit into this space. Never feel you aren't trying to center Indigenous methods. And never forget that applying Indigenous methods is way more challenging than replicating westernized research methods."

\subsection{Dissertation Feedback: You Aren't Using Indigenous Methodologies}

When I was writing my methodology chapter, I found it the most challenging chapter to write. I was feeling most disconnected from the students who allowed me to enter their lives through our conversations. When I wrote the analysis section, it was extremely challenging to find the academic language that spoke the relationship I had fostered with the student narratives. Methodology books I was introduced to were primarily steeped in westernized approaches to research. When I read these books, the approaches spoke about the analytical tools used during data analysis. It felt cold, yet I pushed through.

I picked a few approaches that were aligned closely with what I felt I was doing. When it was time to send Section 3 to my advisor, I pushed away the uncomfortable thoughts and told myself, "A done dissertation is a good dissertation".

A few weeks later, I opened up an document sent via email that contained feedback to Section 3. I read the words in typed black and white, "... but you aren't using Indigenous methodologies." Those words reverberated through my eyes, brain, lungs, and heart to my fingers and toes.

\subsection{Being Vulnerable}

Being vulnerable means to see the humanity in others and oneself and engage in actions that foster an ethic of care. As a faculty member who now has been given the responsibility to care for another students' academic learning, I found being vulnerable as one way I can disrupt the idea that the doctoral process is one of hazing and insecurity. I want (my) advisees to feel they can be authentic to their identities in the academy.

When I read the feedback on (my) dissertation methods chapter, I was devastated. I questioned my intelligence and (my) whole dissertation topic. I was hurt that a non- 
Indigenous scholar would tell me, an Indigenous person, that I was not doing Indigenous methodologies. It reminded me of how I felt my Indigeneity had always been questioned in my life. At the moment, I was overcome by emotion, and it took me several days to reopen the document. Even when I reopened the document, I still did not agree with the feedback. I was still angry.

Being on the other end of the doctoral process and now advising students, I have been forced to reconcile that experience. I recognize how power, agency, and performativity allow me to reframe the dissertation feedback situation (Figure 5). I navigated the doctoral process in a very passive state. I performed the research tasks in a manner that I thought was necessary to graduate. I never felt like I was compromising my ethics or values, but I felt like I did not have much agency or know how to center my Indigeneity in (my) dissertation. I do not recall ever addressing how the feedback impacted me with the scholar who provided that feedback. At that time, I felt my doctoral performativity needed to uphold an image of confidence. I steered away from being vulnerable with non-Indigenous mentors. I perpetuated the idea that intellectual contributions needed to be devoid of emotions and that the advisor/mentor-student relationship operated on the assumption that mentors and individuals inherently had authority over (my) dissertation.
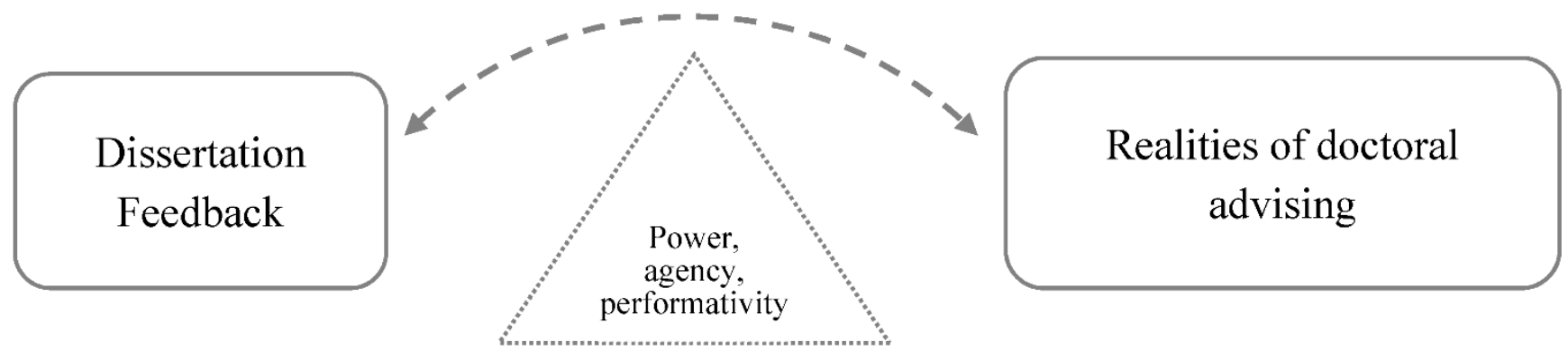

Figure 5. Power, agency, and performativity.

I also steered away from questioning why the feedback felt like an attack on my Indigeneity. Today, I do not believe it was a question about my Indigeneity. I now see how my writing was incomplete and was missing key components of Indigenous methodologies. This is not to say I did not practice key aspects of Indigenous methodologies in (my) dissertation; I did not know how to write about it. I had not been exposed to enough Indigenous scholars and writing to understand how to assert my Indigeneity in the research process. One significant example was how I wrote about compensating the students in (my) dissertation. I relied upon existing western research to justify my practice. However, I knew the compensation for students' participation was more culturally oriented about the practice of gifting (Kimmerer 2013). Culturally, I was taught that one should always give thanks and appreciations, especially to guests. The practice of giving or gifting was not about spending money or boasting of one's financial situation. It was about developing a space of relationality with good intentions.

It is important to note that I have a good heart and mind when reflecting upon my experiences. I do not hold any grievances with how my mentors or dissertation committee supported me. They were very attentive in their manner. However, what was notable is that I never fully understood that the tensions I felt during the doctoral process were repercussions of a system not acknowledging and fostering a need to be unapologetically Indigenous. Through good intentions I am able to reconcile my experiences and learn how to be vulnerable with myself and relatives that enter my life. In the case of advising, it has taught me the need to be vulnerable with the students I provide advice to.

As an advisor to doctoral students and dissertation committees, I strive to foster a doctoral process that is meaningful to my advisees. I want students, in particular Black, Indigenous, and people of color, to have agency in this process. When I spoke up in my former student's dissertation defense, I recognized that I primarily spoke out of 
feelings being triggered by my own experiences and not wanting an Indigenous student to experience the same hostility I felt. I do not regret saying what I said, because it forced me to engage in vulnerability by asserting my voice in a space that I was new to. So, while an experience was partly driving me, I intended to advocate for an Indigenous student.

In the meantime, I continue to learn about theories and Indigenous methodologies of research. I continue to reflect upon my life experiences to be unapologetically Indigenous. I feel honored to share my experiences with a larger audience. I have many more stories, but these shared experiences are linked in a way that articulates my college journey, from undergraduate to doctoral, as a cyclical process. Ultimately, I find great power in recognizing that sharing my "campus tour story" not only motivated others, but also validated my own experiences and choices.

\section{The Beginning}

The stories shared and my assertions of how I reconciled being unapologetically Indigenous in the academy through authenticity and vulnerability are the beginning of this conversation. I frame this conversation through the doctoral process to bound the framing of my experiences. My decision to center the doctoral process does not mean other stories and events did not inform my understanding. My great-grandfather's teachings helped centered the meaning and purpose behind this article. His teachings remind me to honor relations across space and time. The stories I shared went through several revisions, because I wanted to make sure I was honoring individuals connected to the stories being shared. I had other stories in earlier drafts, but after considering my great-grandfather's teachings of relationships, kinship, and cultural protocols, I decided to highlight stories relevant to higher education research. Stories have energy (Archibald 2008), and I have to be intentional to not replicate harm to my relations, even when I see these stories as helping me heal. To ensure that I have the approval, I contacted the relatives connected to the stories to gain their insight into the pieces and approval to include their role in my life.

I have received their feedback and want to share implications of how the doctoral process is understood and the decolonial futures of being unapologetically Indigenous.

\section{Cyclical Educational (Doctoral) Process}

The doctoral process did not begin when I received my acceptance letter from the graduate school. It began at the creation of the K'awaika and Diné people, and I thrive with their knowledge inside me. While I primarily speak about the doctoral process, I demonstrate the cyclical nature of lived experiences. By failing to honor the continuum of our experiences, we will continue to have incomplete stories. As higher education research develops, I see the need for research to focus on how the genealogies and futurities of our lives can foster new ways of engaging in college pathways and persistence work. This work can unfold in a multitude of ways. First, studies about students need to question the intentions of research. Researchers need to consider the role of authenticity and vulnerability in both their research processes and the lives of the communities they are working with. Stories are more than making meaning of the phenomenon. These stories often hold experiences of intergenerational knowledge. Self-reflexivity is a process that challenges the western constructs of power to evolve our understanding of what it means to engage in transformative thought. Without engaging in transformative self-reflexive practice, we are more likely to replicate and be complicit with oppressive systems that inform our educational society.

\section{Being Unapologetically Indigenous}

The idea of being unapologetically Indigenous in the academy needs to continue to be discussed and theorized. I completely own how I choose to engage in being unapologetically Indigenous in the academy and understand that practice will continually evolve. I follow the lineage of decolonial scholars who embrace the notion that we shall never arrive, because once we think about what we do, we have to question if arrival is informed 
by our colonial orientation to life (Deloria and Wildcat 2001; Cajete 2005; Grande 2015; La Paperson 2017; Patel 2015; Minthorn and Shotton 2018). By accessing perspectives engaging in the discourse of unapologetic Indigeneity, we can continue to learn. I also urge that future works to engage in different methods of inquiry. I have chosen to focus my inquiry on written and reflective stories. Arts-based approaches, like poetry and drawing, will yield more complex understandings of what it means to be unapologetically Indigenous in the academy. Furthermore, having more Indigenous narratives explore this space will elevate the critical Indigenous perspectives need to advance the work toward decolonial praxis.

Funding: This research received no external funding.

Institutional Review Board Statement: Not applicable.

Informed Consent Statement: Not applicable.

Data Availability Statement: Not applicable.

Acknowledgments: Thanks are given to my gracious colleagues for peer feedback. Thanks are also given to students, faculty, and community members that entered my life during the doctoral process. I express my thanks to the ancestors and descendants of the Cheyenne, Arapaho, and Ute Nations, for which I wrote this manuscript on their unceded lands.

Conflicts of Interest: The authors declare no conflict of interest.

\section{References}

Adams, Tony E., and Stacy Holman Jones. 2011. Telling stories: Reflexivity, queer theory, and autoethnography. Cultural Studies? Critical Methodologies 11: 108-16. [CrossRef]

Anguiano, Claudia Alejandra. 2011. Undocumented, Unapologetic, and Unafraid: Discursive Strategies of the Immigrant Youth DREAM Social Movement. Ph.D. thesis, University of New Mexico, Albuquerque, NM, USA. Available online: https:// digitalrepository.unm.edu/cj_etds/24 (accessed on 15 December 2020).

Archibald, Jo-ann. 2008. Indigenous Storywork: Educating the Heart, Mind, Body, and Spirit. Vancouver: UBC Press.

Ballew, Reva Lynn. 1996. The experience of Native American Women Obtaining Doctoral Degrees in the Psychology at Traditional American Universities. (Order No. 9708985). Available from ProQuest Dissertations \& Theses Global. (304270420). Available online: https://du.idm.oclc.org/login?url=https:/ / www-proquest-com.du.idm.oclc.org/dissertations-theses/experience-nativeamerican-women-obtaining/docview/304270420/se-2?accountid=14608 (accessed on 15 December 2020).

Bennett, Cheryl. 2018. Another type of hate crime: Violence against American Indian women in reservation border towns. In Crime and Social Justice in Indian Country. Tucson: University of Arizona Press, pp. 21-38.

Cajete, Gregory A. 2005. American Indian epistemologies. New Directions for Student Services 2005: 69-78. [CrossRef]

Deloria, Vine, Jr., and Daniel Wildcat. 2001. Power and place: Indian education in America. Golden: Fulcrum Publishing.

Foley, Douglas E. 2002. Critical ethnography: The reflexive turn. International Journal of Qualitative Studies in Education 15: 469-90. [CrossRef]

Fox, Mary Jo Tippeconnic. 2009. American Indian Women in higher education: Navigating the doctorate. Studies in the Humanities 36: 69.

Fox, Mary Jo Tippeconnic. 2013. American Indian/Alaska Native women: The path to the doctorate. Journal of American Indian Education 52: 26-44.

González, Juan Carlos. 2006. Academic socialization experiences of Latina doctoral students: A qualitative understanding of support systems that aid and challenges that hinder the process. Journal of Hispanic Higher Education 5: 347-65. [CrossRef]

Grande, Sandy. 2015. Red Pedagogy: Native American Social and Political Thought. Lanham: Rowman \& Littlefield.

Hibbert, Paul. 2013. Approaching reflexivity Through feflection: Issues for critical management education. Journal of Management Education 37: 803-27. [CrossRef]

Kimmerer, Robin Wall. 2013. Braiding Sweetgrass: Indigenous Wisdom, Scientific Knowledge and the Teachings of Plants. Minneapolis: Milkweed Editions.

Kovach, Margaret. 2010. Indigenous Methodologies: Characteristics, Conversations, and Contexts. Toronto: University of Toronto Press.

La Paperson. 2017. A Third University Is Possible. Minneapolis: University of Minnesota Press.

Landry, Andrea. 2018. The Intergenerational resistance of unapologetic Indigenous parents. Indigenous, Otherhood. Available online: https:/ /indigenousmotherhood.wordpress.com/2018/03/27/the-intergenerational-resistance-of-unapologetic-indigenousparents / (accessed on 27 March 2018).

Leary, David, Victor Minichiello, and Jeffrey A. Kottler. 2009. Radical reflexivity in qualitative research. Qualitative Journeys: Student and Mentor Experiences with Research, 49-69. 
Martin, Karen, and Booran Mirraboopa. 2003. Ways of knowing, being and doing: A theoretical framework and methods for indigenous and indigenist re-search. Journal of Australian Studies 27: 203-14. [CrossRef]

Minthorn, Robin Starr, and Heather J. Shotton, eds. 2018. Reclaiming Indigenous Research in Higher Education. New Brunswick: Rutgers University Press.

Negrón-Gonzales, Genevieve. 2014. Undocumented, unafraid and unapologetic: Re-articulatory practices and migrant youth "illegality". Latino Studies 12: 259-78. [CrossRef]

Nicholls, Ruth. 2009. Research and Indigenous participation: Critical reflexive methods. International Journal of Social Research Methodology 12: 117-26. [CrossRef]

Nilson, Caroline. 2017. A journey toward cultural competence: The role of researcher reflexivity in Indigenous research. Journal of Transcultural Nursing 28: 119-27. [CrossRef] [PubMed]

Norton, Lynn, and Yvonne Sliep. 2018. A critical reflexive model: Working with life stories in health promotion education. South African Journal of Higher Education 32: 45-63. [CrossRef]

Parkes, Amy. 2016. Reflexivity as autoethnography in Indigenous research. In Critical and Creative Research Methodologies in Social Work. Abingdon-on-Thames: Routledge, pp. 107-20.

Patel, Leigh. 2015. Decolonizing Educational Research: From Ownership to Answerability. New York: Routledge.

Patterson, Ashley, Valerie Kinloch, Tanja Burkhard, Ryann Randall, and Arianna Howard. 2016. Black feminist thought as methodology: Examining intergenerational lived experiences of Black women. Departures in Critical Qualitative Research 5: 55-76. [CrossRef]

Russell-Mundine, Gabrielle. 2012. Reflexivity in Indigenous research: Reframing and decolonising research? Journal of Hospitality and Tourism Management 19: 1-5. [CrossRef]

Shotton, Heather J. 2018. Reciprocity and nation building in Native women's doctoral education. American Indian Quarterly 42: 488-507. [CrossRef]

Shotton, Heather J., Amanda R. Tachine, Christine A. Nelson, Robin Zape-tah-hol-ah Minthorn, and Stephanie J. Waterman. 2018. Living our research through Indigenous scholar sisterhood practices. Qualitative Inquiry 24: 636-45. [CrossRef]

Smith, Linda Tuhiwai. 2013. Decolonizing Methodologies: Research and Indigenous Peoples, 2nd ed. London: Zed Books Ltd.

Tachine, Amanda R. 2015. Monsters and weapons: Navajo students' stories on their journeys toward college. Ph.D. thesis, University of Arizona, Tucson, Arizona.

Tomaselli, K., L. Dyll, and M. Francis. 2008. "self" and "other": Auto-reflexive and indigenous ethnography. In Handbook of Critical and Indigenous Methodologies. Edited by Norman K. Denzin, Yvonne S. Lincoln and Linda T. Smith. Thousand Oaks: SAGE Publications, Inc., pp. 347-72. [CrossRef]

Wilson, Katie, and Judith Wilks. 2013. Research with indigenous children and young people in schools: Ethical and methodological considerations. Global Studies of Childhood 3: 142-52. [CrossRef]

Wilson, Shawn. 2001. What is an Indigenous research methodology? Canadian Journal of Native Education 25: 175-79.

Wilson, Shawn. 2008. Research Is Ceremony: Indigenous Research Methods. Winnipeg: Fernwood.

Yazzie, Melanie. 2014. Brutal violence in Border Towns linked to colonization. Indian Country Today, August 22.

Ziabakhsh, Shabnam. 2015. Reflexivity in evaluating an Aboriginal women heart health promotion program. Canadian Journal of Program Evaluation, 23-40. [CrossRef] 